\title{
EFFICACY OF COMMAND-AND-CONTROL AND MARKET-BASED ENVIRONMENTAL REGULATION IN DEVELOPING COUNTRIES
}

\author{
Allen Blackman \\ (corresponding author) \\ Inter-American Development Bank \\ Washington, DC \\ allenb@iadb.org \\ Zhengyan Li \\ Indiana University School of Public and Environmental Affairs \\ Bloomington, IN \\ zl31@umail.iu.edu \\ Antung A. Liu \\ Indiana University School of Public and Environmental Affairs \\ Bloomington, IN \\ aaliu@indiana.edu
}

Draft: November 15, 2017

Posted with permission from the Annual Review of Resource Economics, Volume 10 @ 2018 by Annual Reviews, http://annualreviews.org/. 


\title{
EFFICACY OF COMMAND-AND-CONTROL AND MARKET-BASED
}

ENVIRONMENTAL REGULATION IN DEVELOPING COUNTRIES

\begin{abstract}
Like their counterparts in industrialized countries, environmental regulators in developing countries rely principally on two types of instruments: command-and-control (CAC) policies, such as emissions and technology standards, and to a lesser extent, marketbased incentives (MBIs), such as emissions fees and tradable permits. But these regulators often lack the capacity to implement, monitor and enforce CAC and MBI policies. As a result, the efficacy of those policies is an empirical matter. We review emerging experimental and quasi-experimental evidence on CAC and MBI policies in developing countries, specifically, 32 studies of CAC policies and 9 studies of MBIs. Although drawn from a small and decidedly nonrandom sample of countries and policy types, the evidence clearly indicates that $\mathrm{CAC}$ and $\mathrm{MBI}$ policies can have significant environmental benefits in developing countries. In addition to cataloging and reviewing this evidence, we discuss data and methodological challenges to augmenting it and suggest directions for future research.
\end{abstract}

Keywords: command-and-control, market-based incentives, developing country

JEL codes: O13, O18, Q01, Q53, Q56 


\section{INTRODUCTION}

The global South is home to the world's worst environmental problems. For example, the 10 cities with the world's worst air quality are all in developing countries, as are many of the most polluted rivers (WHO 2016; Marlier et al. 2016). This pollution has serious adverse consequences at both local and global levels. The World Health Organization estimates that pollution causes 8.4 million deaths per year in developing countries, including 6.7 million from air pollution, 0.8 million from water pollution and poor sanitation, and 1.0 million from toxic and industrial wastes (Landrigan \& Fuller 2015; GAHP 2014). And each year, developing countries, led by China and India, contribute roughly two-thirds of global greenhouse gas emissions (EC JRC/PBL 2012).

Like their counterparts in industrialized countries, environmental authorities in developing countries rely principally on two types of regulation: command-and-control (CAC) policies and, to a lesser extent, market-based incentives (MBIs). CAC regulations like emissions standards and technology standards mandate how much and/or how polluters abate. MBI regulations, by contrast, create economic incentives for abatement. The main types are emissions fees (fees per unit of emissions), marketable permits (emissions allowances that can be traded among polluters), and environmental taxes (taxes on the inputs or outputs).

A salient feature of CAC and most types of MBI policies is that they depend on environmental regulatory capacity to be effective: regulators must check compliance and sanction violators. In developing countries, however, regulatory monitoring and enforcement are inhibited by gaps and inconsistencies in written legislation, weak (undermanned and 
underfunded) regulatory institutions, a lack of political will for stringent enforcement, a shortage of public pollution control facilities like wastewater treatment plants, and an abundance of difficult-to-monitor small and informal firms (Russell \& Vaughan 2003; Eskeland \& Jimenez 1992). As a result, the efficacy of CAC and MBI policies in developing countries is an empirical matter: we need rigorous evaluations to understand whether and under what conditions they generate the intended environmental benefits.

As discussed below, the past decade has seen a significant uptick in studies using rigorous empirical methods to evaluate the effects of CAC and MBI regulations in developing countries. To our knowledge, a comprehensive review of this evidence has yet to appear. This paper aims to help fill that gap. To make the review both manageable and focused we have used the following criteria for including studies in the review. We focus on those that:

- have been published in peer-reviewed journals;

- examine policies in developing (versus transitioning) countries;

- analyze "brown" regulations addressing air, water, solid waste, and hazardous waste pollution, not "green" regulations governing natural resources such as fisheries, forests, and agriculture;

- analyze policies that require environmental regulators to check compliance and sanction violators;

- use rigorous impact evaluation methods that aim to control for confounding factors; and

- address the efficacy of regulations in generating benefits. 
In addition, we put more emphasis on papers using longitudinal data than on those using cross-sectional data.

The remainder of the paper is organized as follows. Section 2 presents a simple heuristic model of a plant's pollution abatement decision. The purpose is to underpin the discussion of the literature. Section 3 briefly discusses data and the methodological challenges of evaluating environmental regulatory efficacy in developing countries. Section 4 examines $\mathrm{CAC}$ regulation and has subsections on stationary source regulations, mobile source regulations. Section 5 looks at MBI regulation, with subsections on environmental fees and tradable permits. The final section summarizes and discusses the findings.

\section{HEURISTIC MODEL}

To facilitate the discussion of the literature that follows, this section briefly presents a simple, often used heuristic model of a plant's choice of how much pollution to emit or, alternatively, how much to abate (e.g., Pargal \& Wheeler 1996; World Bank 2000). The model assumes that plants consider two types of costs when choosing an optimal level of emissions. First, both regulators and other external parties —including local communities, capital markets, and consumers_-penalize the plant for polluting. The expected marginal (pecuniary and nonpecuniary) penalty (EMP) increases with the level of emissions because each additional unit of emissions generates greater damages to human health and the environment. Second, plants must pay to abate emissions by investing in pollution control and prevention. The marginal abatement cost (MAC) decreases with the level of emissions because these investments generate diminishing returns. The plant will choose a level of 
emissions that minimizes the sum of these two types of costs - that is, the level at which the EMP is equal to the MAC.

As illustrated in Figure 1, the plant's EMP schedule increases with the level of emissions, and its MAC schedule decreases with the level of emissions. The plant's costminimizing level of emissions, E1, is determined by the intersection of the EMP1 and MAC1 schedules. If the plant is required by law to meet an emissions standard, R, the EMP schedule is discontinuous at R. Policies that enhance regulatory or nonregulatory pressures will shift the EMP schedule up (to EMP2), and those that cut abatement costs will shift the MAC schedule down (to MAC2). Both types of policies will reduce E1.

The fundamental issue observed by the literature is that regulatory pressure is weak, for the reasons listed in the introduction: weak regulatory institutions, a lack of political will for stringent enforcement, a shortage of public pollution control facilities, and an abundance of difficult-to-monitor small and informal firms. In terms of our graphical model, the result is that the EMP schedule lies close to the horizontal axis. Many of the studies reviewed in subsequent sections effectively test whether imposition of a CAC or MBI policy shifts that schedule up and shifts equilibrium emissions to the left.

[Insert Figure 1 here]

\section{CHALLENGES TO EVALUATING ENVIRONMENTAL REGULATORY}

\section{EFFICACY}

Conducting rigorous empirical research on the efficacy of CAC and MBI regulation in developing countries is challenging, for several reasons. First, credible data on environmental outcomes - in particular, facility-level data collected by regulators — are scarce. In most 
developing countries, such data simply do not exist. When they do, they are often selfreported and unverified. Also, they often suffer from selection bias: plants that regularly selfreport tend to be superior environmental performers. Given these problems, many of the studies we review in this article rely on other types of data. For example, among the 32 studies examining CAC regulations discussed below, only 6 rely on official plant-level data (Table 2). The rest use environmental quality data at the level of an administrative unit, monitoring station, or vehicle, or they use original plant-level survey data.

Second, disentangling the effects of a specific regulatory policy on environmental performance from the effects of other regulatory policies can be difficult. Government programs addressing serious pollution problems are often multifaceted, entailing a suite of policies implemented concurrently. For example, China implemented a portfolio of policies to quickly improve air quality in Beijing and other cities during the 2008 summer Olympic Games, including closing major polluting facilities, mandating installation of abatement devices in coal-fired power plants, and imposing more stringent emissions standards (He et al. 2016). And in Santiago, Chile, regulators rely on CAC emissions standards, tradable permits, license-based driving restrictions, and episodic plant closures to improve air quality (Mullins \& Bharadwaj 2012).

Third, disentangling the effects of a specific regulation on environmental performance from the effects of omitted variables can be challenging. One reason is that regulators and communities surrounding dirty plants may pressure those plants to improve their environmental performance, a phenomenon that occurs all over the world but is arguably particularly prominent in developing countries, where community pressure sometimes drive variation in environmental regulatory stringency (Blackman \& Bannister 1998; Pargal \& 
Wheeler 1996). A study that failed to control for community pressure might overstate the effect of regulation.

Finally, reverse causality can confound treatment effects estimates. For example, regulators often target particularly dirty plants for enforcement (e.g., Blackman et al. 2010). A study of the effect of enforcement on environmental outcomes that did not control for that targeting could generate a spurious negative correlation between enforcement and environmental performance. This is a challenge in evaluating the efficacy of regulations in both industrialized and developing countries.

\section{COMMAND-AND-CONTROL REGULATION}

Overall, the emerging evidence on the effectiveness of CAC regulation in developing countries indicates that it can generate intended benefits; of the 32 studies summarized below, 24 (75 percent) find that CAC regulation has had some benefit (Tables 1 and 2). The first subsection below examines the evidence on regulating stationary source pollution, with further subsections on the type of regulation examined (covering both air and water pollution, only air, and only water). The next subsection summarizes the evidence on mobile source pollution, focusing on increasingly popular license plate-based driving restrictions but also looking at other instruments.

[Insert Tables 1 and 2 here] 


\subsection{Stationary sources}

\subsubsection{Air and water pollution}

All of the four studies we found that use panel data to assess the effects of CAC regulations covering both air and water pollution conclude that at least some of these regulations have had benefits. Greenstone \& Hanna (2014) examine the effects of CAC regulations implemented at the city level in India-specifically, Supreme Court Action Plans (SCAPs) for improved air quality and mandates for catalytic converters, and the National River Conservation Plan (NRCP). SCAPs typically impose a suite of policies, including fuel regulations, road building, and emissions standards for stationary sources. The NRCP focuses on improving water quality via domestic and industrial wastewater treatment. The authors use city-level data along with generalized difference-in-differences models to examine the effects of these policies on three measures of air pollution, three measures of water pollution, and infant mortality. They find that both SCAPs and catalytic converter mandates generated substantial improvements in air quality, and the catalytic converter mandate led to modest reductions in infant mortality. The NRCP, however, had no discernible effects.

To our knowledge, the only published study of CAC regulations in a developing country based on a randomized controlled trial is Duflo et al. (2013). The authors evaluate the effect of a randomly assigned intervention aimed at improving the responsiveness of industrial polluters to various CAC environmental regulations in Gujarat, India. The intervention altered the market structure of third-party environmental audits, the primary means by which regulators monitor compliance with CAC policies. Specifically, for randomly selected plants that received the intervention, the auditors were paid from a central pool rather than by the plant, were randomly assigned to inspect plants instead of having 
longstanding responsibilities for certain plants, were monitored via follow-up visits replicating their inspections, and were paid conditional on their reporting accuracy. Duflo et al. find that the intervention caused auditors to report more truthfully and caused plants to reduce emissions, presumably because they understood that monitoring of noncompliance was more reliable. From the perspective of the present review, these results clearly indicate that CAC regulations can be effective.

Two studies use panel data to examine CAC regulations in China. Jin \& Lin (2014) use 1992-2008 province-level panel data along with fixed effects models to examine the effect of, among other things, province-level pollution control targets for chemical oxygen demand (COD) water pollution and sulfur dioxide air pollution. Provincial officials' promotions are linked to compliance with these targets, which are set under China's five-year plans. Jin \& Lin find that the targets spur reductions in both COD and sulfur dioxide. Dasgupta et al. (2001) use 1993-1997 firm-level data to analyze the effect of regulatory inspections on polluting emissions (total suspended particulates air pollution, COD, and total suspended solids water pollution). To control for the endogeneity of inspections, they estimate a system of simultaneous equations. They conclude that the inspections caused reductions in both air and water pollution.

Finally, five studies, which on average are somewhat older than those summarized above, use cross-sectional plant-level data to examine the effects of CAC regulations on multiple types of pollution. In some cases, the data and/or empirical design have limitations. However, the results are consistent: all find that CAC policies are linked to some type of environmental practice or benefit. Both Dasgupta et al. (2000) and Escobar \& Chavez (2013) examine, among other things, effects of regulatory inspections in Mexico. Dasgupta et al. (2000) find a link between inspections and environmental management system adoption, and 
in turn a link between adoption and self-reported regulatory compliance. Escobar and Chavez (2013) identify a correlation between inspections and compliance reports from those inspections. Féres \& Reynaud (2012) find that a measure of the intensity of CAC regulation is correlated with pollution abatement expenditure in Brazil. Seroa da Motta (2006) concludes that regulatory sanctions help explain the number of environmental practices that polluters adopted in Brazil. And Zhao et al. (2015) find that self-reported strength of CAC regulations helps explain carbon emissions from Chinese power plants.

\subsubsection{Air pollution}

Seven studies use panel data to examine the effects of CAC air pollution regulations. All but one find these regulations have had some benefits.

\section{Environmental episode days in Santiago, Chile}

In 1997, Chilean regulators established an "environmental episode" policy that imposes additional controls on both stationary and mobile sources in Santiago on days when coarse particulate air pollution (PM10) is projected to exceed defined thresholds. These controls include shutting down major stationary sources, prohibiting the burning of biomass for home heating, and including additional vehicles in the city's driving restrictions program (see Section 4.2.1, below). Mullins \& Bharadwaj (2012) examine the regulations' effect on PM10 air pollution and all-cause mortality. They use day-level data along with a matched difference-in-differences approach, essentially comparing changes in outcomes on days following declaration of an environmental episode with changes in outcomes on similar days with similar pollution levels prior to the implementation of the 1997 regulation. They find 
that the regulation reduced PM10 by about a fifth on the day of implementation and cut mortality among the elderly. Both effects persisted on days following the environmental episode. Tronosco et al. (2012) use similar data along with a simpler event study approach to examine the effects of environmental episode days on a broader set of air pollutants, including carbon monoxide, nitrogen oxides, sulfur dioxide, and fine particulates (PM2.5). They find that the regulation cut carbon monoxide, nitrogen oxides (both mainly emitted mainly by vehicles) and both coarse and fine particulates but not sulfur dioxides (mainly emitted by point sources). Finally, Coria (2009) uses stationary source-level panel data along with a duration model to determine whether environmental episode days (as well as Santiago's emissions permit trading system) help explain these sources' decisions to switch en mass from relatively dirty fuels to natural gas in the late 1990s and early 2000s. She concludes that they did not. Rather, the falling price of natural gas was mostly responsible for the switch.

\section{The 2008 Beijing Olympic Games}

Two studies examine the effects on air quality and health outcomes of the suite of CAC regulations China put in place to quickly improve air quality in Beijing, neighboring cities, and other host cities during the 2008 summer Olympic Games. Implemented between late 2007 and late 2008, these regulations affected both stationary and mobile sources. The stationary source measures included closing (either permanently or temporarily) major polluting facilities, relocating others, halting large construction projects, mandating installation of abatement devices in coal-fired power plants, imposing more stringent emissions standards, and requiring oil and gas collection and recovery systems to be installed in gas stations, oil storage facilities, and tankers. Mobile source measures included increasing 
gas prices, ratcheting up mobile source emissions standards, restricting driving (see Section 4.2.1 below), and replacing all heavy-emitting vehicles. He et al. (2016) analyze the effect of all of these regulations on air pollution and mortality in Beijing and neighboring and host cities. They use city-month-level data on PM10 generated by ground monitoring stations in 34 cities ( 8 treatment cities and 26 control cities) along with generalized difference-indifferences models. They find that the Olympics regulations reduced PM10 by 10 percent and all-cause mortality by 8 percent. Chen et al. (2013) use similar data and methods to analyze the effect of the Olympics regulations on air quality. However, they focus on Beijing, use a different sample of cities and different measures of air pollution, and supplement air quality data from ground monitors with satellite-based measures of aerosol optical depth. They find that the Olympics regulations reduced an air pollution index by a quarter during the games, but the effect dissipated quickly thereafter. ${ }^{1}$

\section{Miscellaneous regulations on stationary sources}

Tanaka (2015) analyzes the effect of China's 1998 Two Control Zone policy, which is aimed at reducing power plant emissions nationwide, on infant mortality. Applied in 175 prefectures where ambient air quality exceeded a national standards, this policy shut down small, inefficient power plants and required larger ones to install abatement devices. Using county- and prefecture-level panel data for 145 jurisdictions along with a difference-indifferences model, the author finds that the Two Control Zone policy reduced infant mortality by one-fifth.

\footnotetext{
${ }^{1}$ In addition to these two quasi-experimental studies, a number of studies have focused reported trends in air quality before and after the Olympic Games (see, e.g., Wang et al. 2009).
} 
Hanna \& Oliva (2015) examine the effects on sulfur dioxide air pollution and labor supply of the 1991 closure of a highly polluting oil refinery in Mexico City. Although the study focuses on the link between air pollution reductions and labor supply, it also sheds light on the effects of the CAC mandate that shuttered the refinery. The authors use census tractlevel panel data along with a generalized difference-in-differences model in which census tracts within $5 \mathrm{~km}$ of the refinery are considered to have been "treated." They find that in these areas, the closure reduced sulfur dioxide pollution by 20 percent and increased hours worked per week by 4 percent.

\subsubsection{Water pollution}

Two studies examine the effects of CAC water pollution regulations. Both find they had significant benefits. Khan et al. (2015) focus on 2006 Chinese regulations aimed at reducing discharges of chemical oxygen demand (COD) from plants just upstream of jurisdictional borders. The 2006 regulations tied local officials' promotions to their success in reducing such border pollution. The authors use 2004-2010 monitoring station-level panel data from 499 monitoring stations along China's seven major rivers along with difference-indifferences models to test whether these regulations met that goal, in effect comparing changes in pollution levels at monitoring stations just upstream from borders with changes at monitoring stations far from borders. They find that the regulation led to significant reductions in COD.

Liu et al. (In Press) examine the effects on COD and labor demand of 2004 regulations mandating more stringent discharge standards for textile printing and dyeing plants in the Lake Tai region of Jiangsu Province, China. They use 2002-2007 plant-level 
data from 661 facilities along with difference-in-difference models, essentially comparing changes in outcomes at textile plants in the area affected by regulation with changes at plants elsewhere. They find that the regulations reduced COD discharges by more than 20 percent, reduced labor demand by 7 percent, and had stronger effects in certain types of plants, including those that were domestically owned.

Finally, two older studies using cross-sectional data examine the effect of CAC water pollution regulations. Neither is able to discern a significant effect. Wang (2002) uses plantlevel data on more than 1000 Chinese industrial firms along with instrumental variable models to examine the effect of CAC regulations (proxied by location in a designated environmentally sensitive zone and other variables) on abatement expenditures. Blackman \& Kildegaard (2010) use plant-level data on leather tanneries in León, Mexico, along with bivariate probit models to examine the link between CAC regulations governing wastewater discharges (proxied by regulatory inspections) and adoption of clean tanning technologies.

\subsection{Mobile sources}

\subsubsection{License plate-based driving restrictions}

License plate-based driving restrictions aim to reduce air pollution and traffic congestion by prohibiting drivers from using their vehicles one or more days a week based on the last digit of the license plate. Such policies have been implemented in at least a dozen developing country megacities worldwide, including Beijing, Bogotá, Delhi, Quito, Medellin, San José, São Paulo, and Santiago. Recently, these regulations have received considerable attention from economists, with 10 published studies. Findings have been decidedly mixed: 2 
studies have concluded that these programs have at least some perverse effects, 2 find no effects, and 6 find significant benefits.

\section{Mexico City}

Mexico's City's 1989 Day without Driving (Hoy no Circula, HNC) program is probably the world's best known and most studied license plate-based driving restrictions initiative. Until the rules were changed in 2016 to exempt all vehicles that could pass emissions tests, the program prohibited vehicles more than eight years old from being driven one weekday per week and one Saturday per month both in the Federal District and in 19 neighboring counties from 5 a.m. to 10 p.m. Eskeland \& Feyziouglu (1997) evaluate HNC's effects on fuel consumption and vehicle ownership. They use historical data to predict counterfactual outcomes and then compare predicted and actual outcomes. They find that the program actually increased gasoline consumption, most likely because drivers purchased additional vehicles — often gas-guzzling, highly polluting clunkers - so that they could drive on the restricted day.

Almost a decade after that seminal study appeared, Davis (2008) revisited the issue using more comprehensive data and temporal regression discontinuity (interrupted time series) models that aim to identify breaks in trends at the time the program was first implemented. Outcomes analyzed were five types of air pollution (carbon monoxide, nitrogen oxides, ozone, nitrogen oxides, and sulfur dioxide), gasoline sales, vehicle registration and sales, bus ridership, and taxi prices. Davis finds that in general, air pollution did not decline as a result of $\mathrm{HNC}$ and actually increased during weekdays. In addition, vehicle registration and sales increased and bus ridership decreased. 
Gallego et al. (2013a) use a regression discontinuity approach similar to Davis's (2008) but analyze only carbon monoxide and use models with different specifications (e.g., different lengths of the event window, different order polynomials). The results confirm that HNC did not reduce air pollution in the long term. However, the authors find that it did cut air pollution in the first several months after implementation, before drivers had a chance to fully adjust by, for example, buying additional cars.

\section{Beijing}

Beijing's license plate-based driving restrictions program was first implemented in 2008, part of a collection of policies aimed at improving air quality ahead of the Beijing summer Olympic Games (see Section 4.1.2, above). For its first two-month implementation period, which coincided with the Games, the program prohibited driving every other day seven days a week for all but three hours a day (midnight to 3 a.m.). Afterward, it prohibited driving one day per week, first between 6 a.m. and 9 p.m. and later (2009) from 7 a.m. to 8 p.m. Evaluating the effects of Beijing's driving restrictions program is challenging because it coincided with other air pollution control measures and because the one-day-a-week program was preceded by an every-other-day program. Sun et al. (2014) examine the one-day-a-week program's effects on city-wide traffic speed and inhalable particulates. They use day-level data along with a novel generalized difference-in-difference identification strategy based on a plausibly exogenous absence of license plates ending in the digit 4, attributable to a cultural aversion to that number. They say this strategy allows them to disentangle the program's effects from those of concurrent air quality measures. They find that driving restrictions succeeded in increasing average city-wide traffic speeds, but had little effect on concentrations of inhalable particulate matter. 
Viard \& Fu (2015) examine the one-day-a-week program's effects on an air pollution index (of coarse particulates, nitrogen oxides, and sulfur dioxide) and labor supply, proxied by television viewership. Their strategy for disentangling the effects of the program on air quality from those of concurrent air pollution policies is to take advantage not only of the temporal variation in the policy, but also of spatial variation in its effects related to the proximity of air quality monitoring stations to roads. They find that the program reduced air pollution by about one-fifth and increased television viewership 9 to 17 percent for workers with "discretionary work time." They posit that the program has been more effective than the $\mathrm{HNC}$ in Mexico City because purchasing additional vehicles to circumvent driving restrictions is more costly in Beijing, vehicles in Beijing are newer and cleaner, and public transportation in Beijing is cheaper and higher quality. In addition, they provide evidence that rates of compliance with Beijing's program are high.

Finally, Lu (2016) examines the effects of changes in the rules of Beijing's one-day-aweek program after it was first implemented in September 2009. Specifically, he examines an April 2009 decision to narrow by two hours the daily window during which restrictions were in force and a January 2011 decision to, among other things, increase the maximum fine for violations. He uses daily air pollution index data along with a regression discontinuity design similar to Davis's (2008). He finds that the 2009 weakening of the policy led to increases in pollution, and the 2011 strengthening led to reductions.

\section{Bogotá}

First implemented in 1998, Bogotá's driving restrictions policy has undergone three significant revisions. In its initial incarnation, it restricted driving private vehicles for four hours a day: two hours during the morning rush hour and two hours during the evening rush 
hour. In 2001 the evening restriction was extended to cover public vehicles. In 2004 the number of hours during which restrictions were in place for private vehicles was extended to three hours in both the morning and the evening. Finally, in 2009, the number of hours for private vehicles was extended to 14 hours per day, starting at 6 a.m. Bonilla (2016) uses hourly data along with a regression discontinuity approach similar to Davis's (2008) to analyze the effects of the first two phases (1998-2004) and last two phases (2004-2009) of the Bogotá program on concentrations of carbon monoxide (a pollutant primarily emitted by mobile sources), gasoline consumption, and vehicle sales and registrations. He is unable to discern an effect of either set of phases on air quality or vehicle use. However, he finds some evidence that the latter two phases of the program actually led to a perverse increase in fuel consumption, vehicle ownership, and air pollution in morning peak hours.

Zhang et al. (2017) use a similar empirical design to examine the effects of all four phases of the Bogotá program on seven air pollutants (carbon monoxide, PM10, three types of nitrogen oxides, ozone, and sulfur dioxide). They find that in general, the program's different versions have not led to significant overall improvements in air quality. More specifically, they find that the program's effects vary, increasing some pollutants and reducing others, partly as a result of atmospheric chemistry.

\section{Quito and Santiago}

Carrillo et al. (2016) examine Quito's 2010 Pico y Placa (PyP) program, which restricts driving during peak hours in the central part of the city. They use hourly data along with a triple differences design that takes advantage of both temporal and spatial variation in the policy (which applies to only part of the city). They find that the program has reduced carbon monoxide pollution by 9 to 11 percent during peak traffic hours. They speculate that 
this success is attributable to vigorous enforcement, the availability of taxis and public transportation, the high cost of purchasing additional vehicles, and uncertainty about whether the PyP program will be continued, which makes drivers reluctant to invest heavily in adapting to it.

Finally, de Grange \& Troncoso (2011) examine the effects of Santiago's driving restriction program. Since the late 1980s, this program has prohibited driving vehicles without catalytic converters one day a week during morning rush hours in the autumn and winter. Since the mid-1990s, a more stringent version of the program was implemented: it applies to all vehicles on environmental episode days, when air pollution is predicted to exceed certain thresholds (see Section 4.1.2, above). De Grange \& Troncoso use hourly data along with regression discontinuity models to examine the effects of the original and additional programs on automobile, metro, and bus trips. They find that the original restrictions have not affected the use of private vehicles. However, the additional restrictions reduced private vehicle use by 6 percent and increased metro use by 3 percent.

\subsubsection{Other regulations on vehicular emissions}

Vehicular emissions standards are common in developing countries. Oliva (2015) examines testing for compliance with such standards in Mexico City, focusing on a common corrupt practice: bribing testing center technicians to use emissions results from clean "donor cars." She identifies test centers that engage in this practice from telltale serial correlation in their emissions test results when they use the same vehicle for consecutive tests. Then, using data from "clean" test centers only, she estimates the fair probability of vehicles' passing the test conditional on their observed characteristics. Finally, she estimates a structural model of car owners' testing decisions. Her results indicate that roughly 10 percent of car owners cheat 
on emissions tests and that eliminating such cheating would significantly reduce vehicular emissions. Although the paper does not directly test for it, the study clearly bears on the effectiveness of vehicular emissions standards.

Finally, Kathuria (2002) examines a suite of more than 20 CAC regulations aimed at reducing vehicular emissions in Delhi, including conversion of all commercial vehicles to compressed natural gas, phasing out older commercial vehicles, and ratcheting up emissions standards. The regulations were implemented between 1998 and 2001. To identify the effect of these policies on particulate air pollution and nitrogen oxides, he uses daily 1999-2001 air quality data along with simple event study regression models. He is unable to discern an effect of any of these policies, a finding he attributes to the rapid growth in new vehicle registrations during the study period.

\section{MARKET-BASED INSTRUMENTS}

Our discussion of market-based instruments focuses on emissions fees and tradable permits. Both require environmental regulators to check compliance and sanction violators, and thus their efficacy in developing countries is open to question. We leave aside environmental taxes (taxes on inputs and outputs associated with pollution), which in general do not require such regulatory inputs. In theory, both emissions fees and tradable permits should have an unambiguous effect in reducing emissions. However, in developing countries, the actual effects are unclear because of tax evasion (Liu 2014), the informal economy (Bento et al. 2017), and as just noted, limited monitoring and enforcement (Blackman \& Harrington 2000; Blackman 2009).

Although a number of papers examine various aspects of MBIs in developing countries, including their advantages and disadvantages relative to $\mathrm{CAC}$ (Blackman and 
Harrington 2000; Caffera 2010), evidence on their actual effectiveness is thin — significantly thinner than the evidence on CAC. We were able to find only eight studies that met our criteria for inclusion (Table 3). These studies focus on emissions fees in China and tradable permits in Santiago, Chile. Overall, the findings are mixed (Table 4). Although five of the six studies of Chinese emissions find at least some benefit, neither of the two studies of tradable permits in Santiago finds that they reduced pollution.

[Insert Tables 3 and 4 here]

\subsection{China's pollution levy system}

\subsubsection{Overview}

China's pollution levy system is a pillar of the country's environmental regulatory system and has been extensively studied. Rolled out nationally in 1982 after three years of local experimentation, the system regulates 29 water pollutants and 22 air pollutants, as well as solid waste, radioactive waste, and noise. The formulas used to calculate levies have evolved over time. ${ }^{2}$ There have been at least three important changes. First, before 1993, levies were assessed only for discharges that exceeded CAC emissions standards; since 1993, all discharges have been regulated. Second, before 2003, polluters were required to pay only for the pollutant associated with the greatest total levy; since 2003, polluters have been required to pay for the three pollutants with the greatest total levy. Finally, before 1995, much of the levies could be rebated to polluters to subsidize investments in pollution reduction equipment; since then, rebates for abatement investments have been converted loans.

\footnotetext{
${ }^{2}$ See Wang \& Wheeler (2005) and Lin (2013) for detailed formulas.
} 
A few researchers have concluded that the peculiarities of the levy system's design have dampened abatement incentives. For example, Lin (2013) argues that because under the current system, plants pay levies only on the three pollutants with the greatest total levy, they have no incentives to abate other pollutants. He also observes that for water pollutants, marginal levy rates are reduced above certain thresholds, which diminishes abatement incentives above those thresholds. In addition, Blackman \& Harrington (2000) point out that because of the wide latitude Chinese firms have in accounting, they may get back some of their levy payments through rebates, whether or not they have invested in pollution reduction equipment. The net effect is to reduce levy rates, again weakening the system's abatement incentives. These design issues, along with the monitoring and enforcement constraints highlighted in the Introduction, imply that rigorous evaluations are needed to assess whether China's pollution levy system actually has environmental benefits.

Probably the greatest challenge in conducting such evaluations is finding reliable data. In China, plant-level environmental performance data are only sporadically available and are not published by the government. Many published papers use plant-level data obtained from national or local environmental protection bureaus (EPBs). As a result, the geographic and temporal scope of these studies is limited. Moreover, the levy system has relied on selfreporting: polluters report their emissions, and regulators inspect and verify the reports. The accuracy of self-reports is questionable.

\subsubsection{Chinese plants' responses to regulatory stringency}

Research on the efficacy of the Chinese pollution levy system typically exploits variation in the stringency of the levy system across plants. There are two main sources of such variation (Wang \& Wheeler 2005). First, emissions standards are set jointly by the 
central and provincial governments. As a result, two otherwise identical plants located in different provinces can be subject to different levies. Second, inspection and levy collection are largely decentralized and the responsibility of local EPBs. Therefore, even aside from the heterogeneity just noted, the number of inspections and levy rates can vary significantly across plants.

A common methodological challenge in assessing the effectiveness of Chinese pollution levies is the codetermination of regulatory stringency and plant behavior: plants change their environmental performance as a result of increased regulatory stringency, but policymakers may also adapt the stringency of regulations (levy rates, inspections) to the environmental performance of regulated plants. To overcome this challenge, some researchers have used a simultaneous equations approach (Jiang \& McKibbin 2002; Wang et al. 2003; Wang \& Wheeler 2005), and others have used instrumental variables to tease out an exogenous portion of variation (Dasgupta et al. 2001; Jin \& Lin 2014; Lin 2013; Wang 2002). Most studies assessing the Chinese levy system find that higher levy rates lead to improvements in environmental performance. Using cross-sectional data on 891 of China's top water polluters in 1993, Wang (2002) finds that investments in pollution abatement facilities and expenditures on operating those facilities responded strongly to effective levy rates, defined as the levy actually paid for pollution per unit of emissions. He instruments for the effective levy rate using region-level socioeconomic and demographic variables, such as income, education, population density, and environmental complaints. However, it is not clear that these region-level variables do not directly affect plant-level investments and operating expenditures.

Using 1993 state EPB data on 3,000 large air and water polluters, Wang \& Wheeler (2005) find that water pollution emissions declined by 1 percent and air pollution emissions 
by 0.65 percent for each 1 percent increase in the effective levy rate, suggesting that pollution levies generate a strong deterrent effect. The number of regulators per plant and complaints per capita are used to instrument for the effective levy rate. Again, it is not clear that these variables do not directly affect outcomes.

Jiang \& McKibbin (2002) develop a structural model of equilibrium pollution using province-level data on emissions of waste water, waste gas, and solid waste between 1992 and 1996. They find that pollution intensity was highly responsive to the levy rate.

Jin \& Lin (2014) examine the relationships between the effective levy rate, technological efficiency, and pollution intensity using province-level data from 1992 to 2008 . They find that the effective levy rate significantly reduced pollution intensity.

Using data on individual industrial polluters in Zhenjiang between 1993 and 1997, Dasgupta et al. (2001) analyze the effect on total suspended solids and COD water pollution and total suspended particulates air pollution of both pollution levies and regulatory inspections. Time trends are used to instrument for the number of inspections, a method that relies on the assumption that factors affecting emissions are uncorrelated with time. The authors find that although the number of inspections reduced emissions, the pollution levy had a statistically insignificant effect.

Finally, Lin (2013) uses quarterly plant-level data from the food, chemical, paper, and medicine sectors in an unidentified municipality to analyze how regulatory inspections aimed at enforcing pollution levies affected COD water pollution. He uses plausibly exogenous variation in rainfall to instrument for the number of inspections while carefully distinguishing between actual emissions and those self-reported by plants under the fee discharge system. He finds that inspections caused an increase in self-reported emissions. Acknowledging the institutional uncertainties outlined above, Lin does not come to a conclusion about the effect 
on real emissions. His results are opposite those of Dasgupta et al. (2001), a contrast that points to rich opportunities for further research.

\subsection{Santiago's tradable air pollution permits program}

Established in 1997, Santiago's air pollution permit trading program initially focused on particulate matter. Later, its scope was expanded to include nitrous oxides and other pollutants. After the program was implemented, air emissions dropped sharply in Santiago, which has led advocates to say that the program was responsible. Coria \& Sterner (2009) provide detailed background and document the reduction in emissions in the years following the start of the program.

Early studies of the Chilean permit trading program tended to focus on practical implementation issues. Montero et al. (2002) documents a failure to reconcile permits and emissions. They also point out that grandfathered permits created incentives for polluters to overstate their initial emissions, which led to a significant overallocation of permits. Coria et al. (2010) conduct interviews of firms subject to the program and finds that firms complained most about policy implementation - specifically, a lack of transparency, plus uncertainty about the rights associated with permits, the schedule for monitoring, and the penalties for noncompliance. Palacios \& Chavez (2005) use firm-level data along with a binary choice model to identify the determinants of the compliance decisions. They conclude that the firms' characteristics affected their compliance decisions.

Only two papers, both based on plant-level data, rigorously evaluate the program's efficacy. Using cross-sectional data, Montero et al. (2002) find that fuel switching — from dirty fuels to relatively clean natural gas — was largely responsible for the reduction in air emissions following rollout of the permit trading program; the program itself did not 
encourage that switch. Coria (2009) uses panel data along with a hazard model to compare the importance of the permit trading system with energy prices in inducing the switch. She finds that the effect of the tradable permit system was not significant.

\section{DISCUSSION}

\subsection{Efficacy}

Our review of evidence on CAC and MBI in developing countries clearly shows that such regulations can generate environmental benefits. Of the $32 \mathrm{CAC}$ studies we reviewed, 24 (75 percent) find evidence of benefits (Table 2). Of the $8 \mathrm{MBI}$ studies, 5 (63 percent) find evidence of benefits (Table 4). Overall, of the 40 studies of both types of regulation, 29 (73 percent) find evidence of benefits.

However, those statistics do not indicate that $\mathrm{CAC}$ and MBI regulations are likely to have benefits in developing countries: rather, they almost certainly overstate effectiveness, for two reasons. First, the studies we reviewed are drawn from a small and decidedly nonrepresentative sample of developing countries. By necessity, the rigorous quantitative studies on which we have focused examine countries for which the requisite data are available. One would expect these countries to have relatively strong regulatory and data collection institutions, characteristics that are likely strongly correlated with the effectiveness of CAC regulations. An accounting of the countries covered in our review bears out that hypothesis. The $32 \mathrm{CAC}$ studies focus on only seven countries, Brazil, Chile, China, Colombia, Ecuador, India, and Mexico (Table 2); and the $8 \mathrm{MBI}$ studies focus on only two countries, Chile and China. In 2017, all of these countries except India were classified by the World Bank as upper-middle-income or high-income countries. Moreover, 32 of these studies (80 percent) look at only three countries, China (18), Mexico (8), and Chile (6). Second, 
leaving aside selection bias for certain types of developing countries, among studies focusing on these countries, publication bias is likely to have selected for those showing that regulation was effective. In general, empirical economic studies with positive results are more likely to be published (Franco et al. 2014; Rothstein et al. 2006). Relatedly, researchers have strong incentives to highlight positive results instead of negative ones (Brodeur et al. 2016).

\subsection{Efficacy by type}

The evidence we have reviewed sheds light on the efficacy of certain types of CAC and MBI regulations. We have the most rigorous evidence -10 studies — on license platebased driving restrictions policies. The studies indicate that the permanent driving restrictions programs in Bogotá, Mexico City, and Santiago (leaving aside the temporary environmental episode restrictions in Santiago) had no discernible benefits, had only fleeting ones, or actually exacerbated the problems they aimed to solve. In contrast, the programs in Beijing and Quito succeeded in reducing air pollution and/or traffic congestion. Overall, 6 of the 10 studies demonstrate some benefit, if only temporary. Note, however, that even though this set of studies suggests driving restrictions policies can have significant benefits, they do not necessarily imply that these programs are cost-effective. Emerging evidence on the costs of driving restrictions suggest that they impose very significant costs on drivers (Blackman et al. In Press; Gallego et al. 2013b).

We also have a critical mass of rigorous studies — six — on China's pollution levy program. They suggest that the levy system has improved plants' environmental performance. Four of five studies find that higher levy rates led to improved environmental performance. 
Among the two studies focusing on the effects of inspections, one finds that inspections reduced emissions and one finds they increased reported emissions.

Aside from the evidence on driving restrictions and pollution levies, two studies suggest that Santiago's episodic CAC air pollution regulations, implemented on severe air pollution days, had significant benefits, and two studies suggest that Beijing's efforts to improve air quality during the 2008 Olympic Games, using a suite of CAC policies, were effective.

\subsection{Causal mechanisms}

The evidence we have reviewed provides some hints about causal mechanisms that drive effectiveness of CAC and MBI regulations. Again, we have the most evidence on license plate-based driving restrictions. Although 10 studies are too small a sample from which to draw reliable inferences about causal mechanisms, the authors who documented successful programs in Beijing and Quito have speculated about the factors correlated with effectiveness (Viard \& Fu 2015; Carrillo et al. 2016). These include stringent program enforcement, the high cost and limited availability of vehicles, the low cost and high quality of public transportation, and in the case of Quito, uncertainty about the longevity of restrictions. Two studies suggest that in developing countries, corruption plays a major role in blunting the effect of CAC regulation, and that interventions aimed at checking corruption, such as auditing the auditors, may enhance efficacy (Duflo et al. 2013; Oliva 2015). Finally, two studies hint that tying administrative promotions and job security to regulatory enforcement can enhance efficacy (Jin \& Lin 2014; Khan et al. 2015). 


\subsection{Future research}

Although rigorous quantitative evaluations of CAC and MBI regulations in developing countries are being published more and more frequently — an encouraging trendthe evidence base remains quite thin overall. Several gaps need to be filled. Some gaps correspond to the issues discussed above. First, studies are needed on countries other than upper-middle- and high-income countries like China, Mexico, and Chile. Although data availability is a limiting factor, there surely are middle- and low-income countries where studies are feasible, perhaps using remotely sensed data on air and water quality (Donaldson \& Storeygard 2016).

Second, even for the countries where we have evidence, like China, Mexico, and Chile, more studies are needed of underrepresented regions. For example, most of the existing evidence on China's pollution levy system is based on data provided by municipalities in China's eastern provinces. Studies on other parts of China would paint a more complete picture of the system.

Third, further evidence is needed on MBI regulations in developing countries. We were able to find only eight rigorous studies that met our criteria, and these studies focus on only two MBI policies - pollution levies in China and tradable permits in Santiago. Although the evidence from China is certainly encouraging, the evidence base as a whole does not enable us to generalize about the efficacy of MBIs in developing countries. Given the limited number of studies, it is not possible to disentangle the effects of place-based factors from those related to the policy instruments.

Fourth, further evidence is needed on specific types of CAC regulations. At present, we have a critical mass of studies on only license plate-based driving restrictions, emissions 
fees, and a few other policies. Fifth, outcome variables such as health or environmental quality are rare; these may be of greater policy interest than emissions. Sixth, research with alternative identification strategies, such as regression discontinuity design or propensityscore matching, might help researchers reconcile conflicting conclusions in the current literature on Chinese pollution levies. Finally, studies are needed that identify causal mechanisms associated with successful CAC and MBI policies. 
ACKNOWLEDGMENTS. We are grateful to Sallly Atwater for editorial assistance. 


\section{REFERENCES}

Bento A, Jacobsen M, Liu A. 2017. Environmental policy in the presence of an informal sector. Working paper. Dyson School of Applied Economics and Management, Cornell University.

Blackman A. 2009. Colombia's discharge fee program: Incentives for polluters or regulators? J. Environ. Manag. 90(1):101-19

Blackman A, Bannister GJ. 1998. Community pressure and clean technology in the informal sector: An econometric analysis of the adoption of propane by traditional Mexican brickmakers. J. Environ. Econ. Manag. 35(1):1-21

Blackman A, Harrington W. 2000. The use of economic incentives in developing countries:

Lessons from international experience with industrial air pollution. J. Environ. Dev. $9(1): 5-44$

Blackman A, Kildegaard A. 2010. Clean technological change in developing country industrial clusters: Mexican leather tanneries. Environ. Econ. Policy Studies $12(3): 115-32$

Blackman A, Lahiri B, Pizer M, Rivera Planter M, Muñoz Piña C. 2010. Voluntary regulation in developing countries: Mexico's Clean Industry Program. J. Environ. Econ. Manag. 60(3):182-92

Blackman, A, F Alpízar, F Carlsson and M Rivera. In Press. A contingent valuation approach to estimating regulatory costs: Mexico’s Day without Driving program. J. Assoc. of Environ. and Res. Econ.

Bonilla J. 2016. The more stringent, the better? Rationing car use in Bogotá with moderate and drastic restrictions. World Bank Econ. Rev. 
Brodeur A, Lé M, Sangnier M, Zylberberg Y. 2016. Star wars: The empirics strike back. Am. Econ. J.: Appl. Econ. 8(1):1-32

Caffera, M. 2010. The use of economic instruments for pollution control in Latin America: Lessons for future policy design. Environ. Devel. Econ. 16(3): 247-273.

Carrillo P, Malik A, Yoo Y. 2016. Driving restrictions that work? Quito's Pico y Placa program. Can. J. Eco.n 49(4):1536-68

Chen Y. Zhe Jin G, Kumar N, Shi G. 2013. The promise of Beijing: Evaluating the impact of the 2008 Olympic Games on air quality. J. Environ. Econ. Mana.g 66(3):424-43

Coria J. 2009. Environmental policy, fuel prices and the switching to natural gas in Santiago, Chile. Ecol. Econ. 68(11):2877-84

Coria J, Sterner T. 2009. Tradable permits in developing countries: Evidence from air pollution in Chile. J. Environ. Dev. 19(2):145-70

Coria J, Löfgren A, Sterner T. 2010. To trade or not to trade: Firm-level analysis of emissions trading in Santiago, Chile. J. Environ. Manag. 91(11):2126-33

Dasgupta S, Hettige H, Wheeler D. 2000. What Improves Environmental Compliance?

Evidence from Mexican Industry. J Environ Econ Manag39(1):39-66

Dasgupta S, Laplante B, Mamingi N, Wang H. 2001. Inspections, pollution prices, and environmental performance: evidence from China. Ecol. Econ. 36(3):487-98

Davis L. 2008. The effect of driving restrictions on air quality in Mexico City. J. Pol. Econ. $116(1): 38-81$

de Grange L, Troncoso R. 2011. Impacts of vehicle restrictions on urban transport flows: the case of Santiago, Chile. Transport Policy 18:862e869

Donaldson D, Storeygard A. 2016. The view from above: Applications of satellite data in Economics. J. Econ. Perspect. 30(4):171-98 
Duflo E, Greenstone M, Pande R, Ryan N. 2013. Truth-telling by third-party auditors and the response of polluting firms: experimental evidence from India. Q. J. Econ. 128(4):1499-545

European Commission, Joint Research Centre (EC JRC )/Netherlands Environmental Assessment Agency (PBL). 2012. Emission Database for Global Atmospheric Research ( EDGAR ), EDGARv4.2 FT2012: edgar.jrc.ec.europa.eu

Escobar N, Chávez C. 2013. Monitoring, firms' compliance and imposition of fines: Evidence from the Federal Industrial Inspection Program in Mexico City. Environ. Dev. Econ. 18(6):723-48

Eskeland G, Feyziouglu T. 1997. Rationing can backfire: The "Day without a Car" in Mexico City. World Bank Econ. Rev. 11(3):383-408

Féres J, Reynaud A. 2012. Assessing the impact of formal and informal regulations on environmental and economic performance of Brazilian manufacturing firms. Environ. Resour. Econ. 52(1):65-85

Franco A, Malhotra N, Simonovits G. 2014. Publication bias in the social sciences: Unlocking the file drawer. Science 345(6203):1502-505

Gallego F, Montero J-P, Salas C. 2013a. The effect of transport policies on car use: evidence from Latin American cities. J. Public Econ. 107:47-62.

Gallego F, Montero J-P, Salas C. 2013b. The effect of transport policies on car use: a bundling model with applications. Energy Econ. 40: 585-97.

Global Alliance on Health and Pollution (GAHP). 2014. Global picture of death from pollution. New York. Available at: http://gahp.net/wpcontent/uploads/2017/02/GAHP_General-and-Sample-Country-data-Sep-2014copy.pdf. 
Greenstone M, Hanna R. 2014. Environmental regulations, air and water pollution, and infant mortality in India. Am. Econ. Rev. 104(10):3038-307

Hanna RN, Oliva P. 2015. The effect of pollution on labor supply: Evidence from a natural experiment in Mexico City. J. Public Econ. 122:68-79

He G, Fan M, Zhou M. 2016. The effect of air pollution on mortality in China: Evidence from the 2008 Beijing Olympic Games. J. Environ. Econ. Manag. 79:18-39

Jiang T, McKibbin WJ. 2002. Assessment of China's pollution levy system: an equilibrium pollution approach. Environ. Dev. Econ. 7(1):75-105

Jin Y, Lin L. 2014. China's provincial industrial pollution: the role of technical efficiency, pollution levy and pollution quantity control. Environ. Dev. Econ. 19(1):111-32

Kahn ME, Li P, Zhao D. 2015. Water pollution progress at borders: The role of changes in China's political promotion incentives. Am. Econ. J.: Econ. Policy 7(4):223-42

Kathuria V. 2002. Vehicular pollution control in Delhi Transportation Research Part D: Transport Environ. 7(5):373-87

Landrigan, P, Fuller R. 2015. Global health and environmental pollution. Intern. J. Public Health. DOI 10.1007/s00038-015-0706-7.

Lin L. 2013. Enforcement of pollution levies in China. J. Public Econ. 98:32-43

Liu M, Shadbegian R, Zhang B. In Press. Does environmental regulation affect labor demand in China? Evidence from the textile printing and dyeing industry. J. Environ. Econ. Manag.

Liu AA. 2014. Tax evasion and optimal environmental taxes. J. Environ. Econ. Manag. $66(3): 656-70$

Lu X. 2016. Effectiveness of government enforcement in driving restrictions: A case in Beijing, China. Environ. Econ. Policy Stud. 18(1):63-92 
Marlier, M, Jina A, Kinney P, DeFries R. 2016. Extreme air pollution in global megacities. Current Climate Change Reports 2:15-27.

Montero JP, Sanchez JM, Katz R. 2002. A market based environmental policy experiment in Chile. J. Law Econ. 45(1):267-87

Mullins J, Bharadwaj P. 2012. Effects of short-term measures to curb air pollution: Evidence from Santiago, Chile. Am. J. Agric. Econ. 97(4):1107-34

Oliva P. 2015. Environmental regulations and corruption: Automobile emissions in Mexico City. J. Political Econ. 123(3):686-724

Palacios M, Chávez C. 2005. Determinants of compliance in the emissions compensation program in Santiago, Chile. Environ. Dev. Econ. 10(4):453-83

Pargal S, Wheeler D. 1996. Informal regulation of industrial pollution in developing countries: Evidence from Indonesia. J. Political Econ. 106(6):1314-27

Rothstein HR, Sutton AJ, Borenstein M. 2006. Publication Bias in Metaanalysis: Prevention, Assessment and Adjustments. New York: Wiley

Russell, C and Vaughan W. 2003. The choice of pollution control policy instruments in developing countries: arguments, evidence and suggestions. In International Yearbook of Environmental and Resource Economics, vol. VII. Cheltenham, UK: Edward Elgar.

Seroa da Motta R. 2006 Analyzing the environmental performance of the Brazilian industrial sector. Ecol. Econ. 57(2):269-81

Sun C, Zheng S, Wang R. 2014. Restricting driving for better traffic and clearer skies: Did it work in Beijing? Transportation Policy 32:34-41

Tanaka S. 2015. Environmental regulations on air pollution in China and their impact on infant mortality. J. Health Econ. 42 90-103 
Troncoso R, de Grange L, Cifuentes L. 2012. Effects of environmental alerts and preemergencies on pollutant concentrations in Santiago, Chile. Atmospheric Environ. $61: 550-57$

Viard VB, Fu S. 2015. The effect of Beijing's driving restrictions on pollution and economic activity. J. Public Econ. 125:98-115

Wang H. 2002. Pollution regulation and abatement efforts: Evidence from China. Ecol. Econ. 41(1):85-94

Wang H, Mamingi N, Laplante B, Dasgupta S. 2003. Incomplete enforcement of pollution regulation: Bargaining power of Chinese factories. Environ. Resour. Econ. 24(3):245-62

Wang H, Wheeler D. 2005. Financial incentives and endogenous enforcement in China's pollution levy system. J. Environ. Econ. Manag. 49(1):174-96

Wang W, Primbs T, Tao S, Massey Simonich SL. 2009. Atmospheric particulate matter pollution during the 2008 Beijing Olympics. Environ. Sci. Tech. 43:5314-20

World Bank. 2000. Greening Industry: New Roles for Communities, Markets, and Governments. New York: Oxford

World Health Organization (WHO). 2016. WHO's urban ambient air pollution database Update 2016. Geneva.

Zhang W, Lin Lawell C-YC, Umanskaya VI. 2017. The effects of license plate-based driving restrictions on air quality: Theory and empirical evidence. J. Environ. Econ. Manag. $82: 81-220$

Zhao X, Yin H, Zhao Y. 2015a. Impact of environmental regulations on the efficiency and CO2 emissions of power plants in China. Appl. Energy 149: 238-247 
Figure 1. Manufacturing plant's choice of emissions

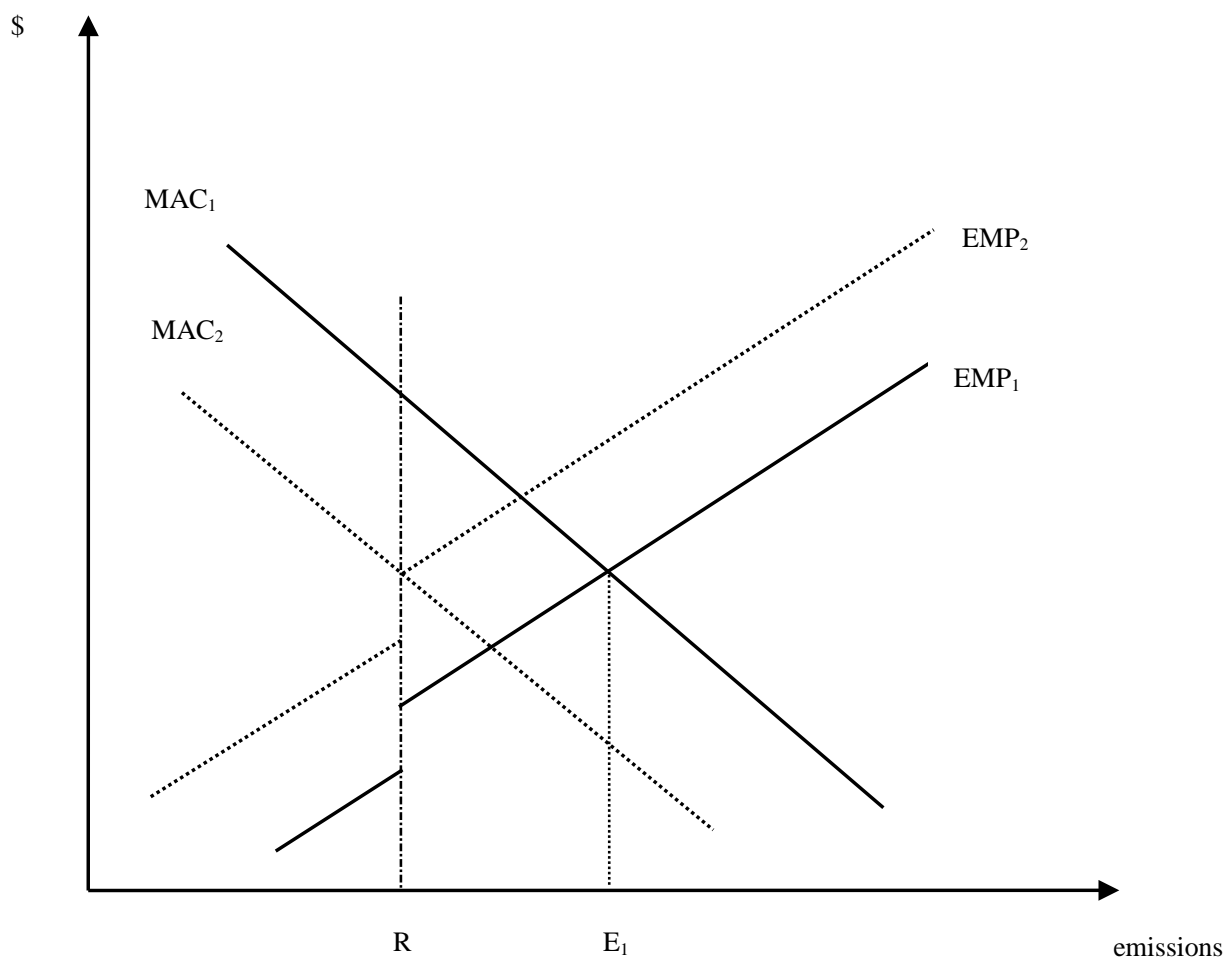

MAC $=$ marginal abatement cost EMP $=$ expected marginal penalty; $\mathrm{R}=$ emissions standard; $\mathrm{E}=$ emissions . 
Table 1. Evidence on effects of command-and-control environmental regulation in developing countries*

\begin{tabular}{|c|c|c|c|c|c|c|}
\hline Category, study & $\begin{array}{l}\text { Study area, } \\
\text { sector }\end{array}$ & Regulation & Outcomes & Data & Methods & Results \\
\hline \multicolumn{7}{|l|}{ Stationary sources } \\
\hline \multirow{2}{*}{\multicolumn{7}{|c|}{$\begin{array}{l}\text { Air and water } \\
\text { Panel data }\end{array}$}} \\
\hline & & & & & & \\
\hline Greenstone \& Hanna (2014) & India & $\begin{array}{l}\text { Supreme Court } \\
\text { Action Plans } \\
\text { (SCAPs) for } \\
\text { improved air } \\
\text { quality and } \\
\text { mandates for } \\
\text { catalytic } \\
\text { converters; } \\
\text { National River } \\
\text { Conservation Plan } \\
\text { (NRCP) }\end{array}$ & $\begin{array}{l}\mathrm{PM}, \mathrm{SO}_{2} \text { and } \\
\mathrm{NO}_{2} \text { air } \\
\text { pollution; } \\
\mathrm{BOD}, \text { Fcoli, } \\
\text { and DO water } \\
\text { pollution; and } \\
\text { infant mortality }\end{array}$ & $\begin{array}{l}\text { City-level } \\
\text { panel }\end{array}$ & DID & $\begin{array}{l}\text { SCAPs and catalytic converter } \\
\text { mandates improved air quality; } \\
\text { catalytic converter mandates } \\
\text { reduced infant mortality; NRCPs } \\
\text { had no discernible effect }\end{array}$ \\
\hline Duflo et al. (2013) & $\begin{array}{l}\text { Gujarat, } \\
\text { India }\end{array}$ & Various & $\begin{array}{l}\text { Accuracy of } \\
\text { third-party } \\
\text { audit reports, } \\
\text { regulatory } \\
\text { compliance }\end{array}$ & $\begin{array}{l}\text { Plant-level } \\
\text { panel }\end{array}$ & $\begin{array}{l}\text { RCT of } \\
\text { intervention } \\
\text { aimed at } \\
\text { improving } \\
\text { quality of third- } \\
\text { party audits }\end{array}$ & $\begin{array}{l}\text { Intervention improved accuracy } \\
\text { of audit reports and regulatory } \\
\text { compliance }\end{array}$ \\
\hline Jin \& Lin (2014) & China & $\begin{array}{l}\text { Province-level air } \\
\text { and water pollution } \\
\text { control targets set } \\
\text { under five-year } \\
\text { plan }\end{array}$ & $\begin{array}{l}\text { COD water } \\
\text { pollution and } \\
\mathrm{SO}_{2} \text { air } \\
\text { pollution }\end{array}$ & $\begin{array}{l}\text { Province- } \\
\text { level panel }\end{array}$ & FE OLS & $\begin{array}{l}\text { Targets spurred reductions in } \\
\mathrm{COD} \text { and } \mathrm{SO}_{2}\end{array}$ \\
\hline Dasgupta et al. (2001) & $\begin{array}{l}\text { Zhenjiang, } \\
\text { China }\end{array}$ & Various & $\begin{array}{l}\text { TSS air } \\
\text { pollution, and } \\
\text { COD and TSS } \\
\text { water pollution }\end{array}$ & $\begin{array}{l}\text { Plant-level } \\
\text { panel }\end{array}$ & $\begin{array}{l}\text { Simultaneous } \\
\text { equations }\end{array}$ & $\begin{array}{l}\text { Regulatory inspections caused } \\
\text { reduction in both air and water } \\
\text { pollution }\end{array}$ \\
\hline \multicolumn{7}{|l|}{ Cross-sectional data } \\
\hline Dasgupta et al. (2000) & Mexico & Various & $\begin{array}{l}\text { EMS adoption, } \\
\text { self-reported } \\
\text { regulatory } \\
\text { compliance }\end{array}$ & $\begin{array}{l}\text { Plant-level } \\
\text { cross-section }\end{array}$ & 2SLS & $\begin{array}{l}\text { Regulatory inspections spurred } \\
\text { EMS adoption, which spurred } \\
\text { compliance }\end{array}$ \\
\hline Escobar \& Chavez (2013) & $\begin{array}{l}\text { Mexico City, } \\
\text { Mexico }\end{array}$ & Various & $\begin{array}{l}\text { Compliance } \\
\text { (among others) }\end{array}$ & $\begin{array}{l}\text { Plant-level } \\
\text { cross-section }\end{array}$ & $\begin{array}{l}\text { Ordered probit } \\
\text { (among others) }\end{array}$ & $\begin{array}{l}\text { Regulatory inspections spurred } \\
\text { compliance }\end{array}$ \\
\hline Féres \& Reynaud (2012) & $\begin{array}{l}\text { Sao Paulo, } \\
\text { Brazil }\end{array}$ & Various & $\begin{array}{l}\text { Total cost, } \\
\text { regulatory } \\
\text { pressure, }\end{array}$ & $\begin{array}{l}\text { Plant-level } \\
\text { cross-section }\end{array}$ & $3 \mathrm{SLS}$ & $\begin{array}{l}\text { Intensity of CAC regulation was } \\
\text { correlated with pollution } \\
\text { abatement expenditure }\end{array}$ \\
\hline
\end{tabular}




\begin{tabular}{|c|c|c|c|c|c|c|}
\hline \multirow{2}{*}{ Seroa da Motta (2006) } & \multirow[b]{2}{*}{ Brazil } & \multirow[b]{2}{*}{ Various } & \multicolumn{4}{|l|}{$\begin{array}{l}\text { pomution } \\
\text { emissions }\end{array}$} \\
\hline & & & $\begin{array}{l}\text { Several } \\
\text { environmental } \\
\text { management } \\
\text { practices }\end{array}$ & $\begin{array}{l}\text { Plant-level } \\
\text { cross-section }\end{array}$ & OLS & $\begin{array}{l}\text { Regulatory sanctions spurred } \\
\text { adoption of environmental } \\
\text { practices }\end{array}$ \\
\hline Zhao et al. (2015) & $\begin{array}{l}\text { China, } \\
\text { electric } \\
\text { power sector }\end{array}$ & Various & $\mathrm{CO}_{2}$ emissions & $\begin{array}{l}\text { Plant-level } \\
\text { cross-section }\end{array}$ & OLS & $\begin{array}{l}\text { Strength of CAC regulations } \\
\text { helps explain carbon emissions }\end{array}$ \\
\hline \multicolumn{7}{|l|}{ Air } \\
\hline \multicolumn{7}{|l|}{ Panel data } \\
\hline Mullins \& Bharadwaj (2012) & $\begin{array}{l}\text { Santiago, } \\
\text { Chile }\end{array}$ & $\begin{array}{l}\text { Environmental } \\
\text { episode days }\end{array}$ & $\begin{array}{l}\text { Ambient PM10 } \\
\text { air pollution, } \\
\text { all-cause } \\
\text { mortality }\end{array}$ & $\begin{array}{l}\text { Day-level } \\
\text { panel }\end{array}$ & Matched DID & $\begin{array}{l}\text { Episode days reduced PM10 by } \\
\text { one-fifth on day of } \\
\text { implementation and cut } \\
\text { mortality among elderly }\end{array}$ \\
\hline Tronosco et al. (2012) & $\begin{array}{l}\text { Santiago, } \\
\text { Chile }\end{array}$ & $\begin{array}{l}\text { Environmental } \\
\text { episode days }\end{array}$ & $\begin{array}{l}\mathrm{CO}, \mathrm{NO} x, \mathrm{SO}_{2} \\
\mathrm{PM} 2.5, \mathrm{PM} 10\end{array}$ & $\begin{array}{l}\text { Day-level } \\
\text { panel }\end{array}$ & $\begin{array}{l}\text { Event study } \\
\text { model }\end{array}$ & $\begin{array}{l}\text { Episode days reduced } \mathrm{CO}, \mathrm{NO}_{x} \text {, } \\
\mathrm{PM} 2.5 \text {, and PM10 but not } \mathrm{SO}_{2}\end{array}$ \\
\hline Coria (2009) & $\begin{array}{l}\text { Santiago, } \\
\text { Chile }\end{array}$ & $\begin{array}{l}\text { Environmental } \\
\text { episode days and } \\
\text { permit trading }\end{array}$ & $\begin{array}{l}\text { Converstion to } \\
\text { natural gas }\end{array}$ & $\begin{array}{l}\text { Plant-level } \\
\text { panel }\end{array}$ & Duration model & $\begin{array}{l}\text { Energy prices, not regulation, } \\
\text { drove switch to natural gas }\end{array}$ \\
\hline He et al. (2016) & China & $\begin{array}{l}\text { Beijing } 2008 \\
\text { summer Olympics } \\
\text { air quality } \\
\text { regulations }\end{array}$ & $\begin{array}{l}\text { PM10 and } \\
\text { mortality }\end{array}$ & $\begin{array}{l}\text { City-level } \\
\text { panel }\end{array}$ & DID & $\begin{array}{l}\text { Regulations reduced PM10 by } \\
10 \% \text { and all-cause mortality by } \\
8 \%\end{array}$ \\
\hline Chen et al. (2013) & China & $\begin{array}{l}\text { Beijing } 2008 \\
\text { summer Olympics } \\
\text { air quality } \\
\text { regulations }\end{array}$ & $\begin{array}{l}\text { Air pollution } \\
\text { index }\left(\mathrm{NO}_{2},\right. \\
\left.\mathrm{SO}_{2}, \mathrm{PM} 10\right) \\
\text { satellite AOD }\end{array}$ & $\begin{array}{l}\text { City-level } \\
\text { panel }\end{array}$ & DID & $\begin{array}{l}\text { Regulations reduced air } \\
\text { pollution index by one-quarter }\end{array}$ \\
\hline Tanaka (2015) & $\begin{array}{l}\text { China, } \\
\text { electric } \\
\text { power sector }\end{array}$ & $\begin{array}{l}\text { Two Control Zone } \\
\text { policy }\end{array}$ & $\begin{array}{l}\text { Infant } \\
\text { mortality }\end{array}$ & $\begin{array}{l}\text { County- and } \\
\text { prefecture- } \\
\text { level panel }\end{array}$ & DID & $\begin{array}{l}\text { Regulations reduced infant } \\
\text { mortality by one-fifth }\end{array}$ \\
\hline Hanna \& Oliva (2015) & $\begin{array}{l}\text { Mexico City, } \\
\text { Mexico }\end{array}$ & Refinery closure & $\begin{array}{l}\mathrm{SO}_{2} \text { air } \\
\text { pollution and } \\
\text { labor supply }\end{array}$ & $\begin{array}{l}\text { Census tract- } \\
\text { level panel }\end{array}$ & DID & $\begin{array}{l}\text { Plant closure reduced } \mathrm{SO}_{2} \\
\text { pollution by one-fifth and } \\
\text { increased hours worked by } 4 \%\end{array}$ \\
\hline \multicolumn{7}{|l|}{ Water } \\
\hline \multicolumn{7}{|l|}{ Panel data } \\
\hline Khan et al. (2015) & China & $\begin{array}{l}2006 \text { border } \\
\text { pollution } \\
\text { regulations }\end{array}$ & COD & $\begin{array}{l}\text { Monitoring } \\
\text { station-level } \\
\text { panel }\end{array}$ & DID & $\begin{array}{l}\text { Regulations led to significant } \\
\text { reductions in COD }\end{array}$ \\
\hline Liu et al. (In Press) & $\begin{array}{l}\text { Jiangsu } \\
\text { Province, } \\
\text { China, } \\
\text { textile sector }\end{array}$ & $\begin{array}{l}\text { Discharge } \\
\text { standards }\end{array}$ & $\begin{array}{l}\text { COD and labor } \\
\text { demand }\end{array}$ & $\begin{array}{l}\text { Plant-level } \\
\text { panel }\end{array}$ & DID & $\begin{array}{l}\text { Standards reduced COD } \\
\text { discharges by more than one- } \\
\text { fifth, and reduced labor demand } \\
\text { by } 7 \%\end{array}$ \\
\hline \multicolumn{7}{|l|}{ Cross-sectional data } \\
\hline Wang (2002) & China & Various & Abatement & Plant-level & IV model & Unable to discern effect \\
\hline
\end{tabular}




\begin{tabular}{|c|c|c|c|c|c|c|}
\hline Blackman \& Kildegaard (2010) & $\begin{array}{l}\text { León, } \\
\text { Guanajuato, } \\
\text { Mexico }\end{array}$ & Various & $\begin{array}{l}\text { expenditures } \\
\text { Adoption of } \\
\text { clean } \\
\text { technologies }\end{array}$ & $\begin{array}{l}\text { cross-section } \\
\text { Plant-level } \\
\text { cross-section }\end{array}$ & Bivariate probit & Unable to discern effect \\
\hline \multicolumn{7}{|l|}{$\begin{array}{l}\text { Mobile sources } \\
\text { Driving restrictions }\end{array}$} \\
\hline Eskeland \& Feyziouglu (1997) & $\begin{array}{l}\text { Mexico City, } \\
\text { Mexico }\end{array}$ & $\begin{array}{l}\text { License plate-- } \\
\text { based driving } \\
\text { restrictions }\end{array}$ & $\begin{array}{l}\text { Fuel } \\
\text { consumption } \\
\text { and vehicle } \\
\text { ownership }\end{array}$ & $\begin{array}{l}\text { City-level } \\
\text { longitudinal }\end{array}$ & See text & $\begin{array}{l}\text { Restrictions increased fuel } \\
\text { consumption }\end{array}$ \\
\hline Davis (2008) & $\begin{array}{l}\text { Mexico City, } \\
\text { Mexico }\end{array}$ & $\begin{array}{l}\text { License plate- } \\
\text { based driving } \\
\text { restrictions }\end{array}$ & $\begin{array}{l}\mathrm{CO}, \mathrm{NO}_{2}, \mathrm{O}_{3}, \\
\mathrm{NO}_{x}, \mathrm{SO}_{2}, \\
\text { gasoline sales, } \\
\text { vehicle } \\
\text { registration and } \\
\text { sales, bus } \\
\text { ridership, and } \\
\text { taxi prices }\end{array}$ & $\begin{array}{l}\text { City-level } \\
\text { longitudinal }\end{array}$ & $\mathrm{RD}$ & $\begin{array}{l}\text { Air pollution did not decline and } \\
\text { increased during weekdays; } \\
\text { vehicle registration and sales } \\
\text { increased and bus ridership } \\
\text { decreased }\end{array}$ \\
\hline Gallego et al. (2013a) & $\begin{array}{l}\text { Mexico City, } \\
\text { Mexico }\end{array}$ & $\begin{array}{l}\text { License plate-- } \\
\text { based driving } \\
\text { restrictions }\end{array}$ & $\mathrm{CO}$ & $\begin{array}{l}\text { City-level } \\
\text { longitudinal }\end{array}$ & $\mathrm{RD}$ & $\begin{array}{l}\text { CO decreased short run but not } \\
\text { long run }\end{array}$ \\
\hline Sun et al. (2014) & $\begin{array}{l}\text { Beijing, } \\
\text { China }\end{array}$ & $\begin{array}{l}\text { License plate-- } \\
\text { based driving } \\
\text { restrictions }\end{array}$ & $\begin{array}{l}\text { City-wide } \\
\text { traffic speed } \\
\text { and inhalable } \\
\text { particles }\end{array}$ & $\begin{array}{l}\text { City-level } \\
\text { longitudinal }\end{array}$ & DID & $\begin{array}{l}\text { Restrictions increased city-wide } \\
\text { traffic speed }\end{array}$ \\
\hline Viard \& Fu (2015) & $\begin{array}{l}\text { Beijing, } \\
\text { China }\end{array}$ & $\begin{array}{l}\text { License plate-- } \\
\text { based driving } \\
\text { restrictions }\end{array}$ & $\begin{array}{l}\text { Air pollution } \\
\text { index }\left(\mathrm{NO}_{2},\right. \\
\left.\mathrm{SO}_{2}, \mathrm{PM} 10\right) \\
\text { TV viewership }\end{array}$ & $\begin{array}{l}\text { City-level } \\
\text { longitudinal }\end{array}$ & DID & $\begin{array}{l}\text { Restrictions reduced air } \\
\text { pollution by about one-fifth and } \\
\text { increased TV viewership 9-17\% } \\
\text { for workers with "discretionary } \\
\text { work time." }\end{array}$ \\
\hline $\mathrm{Lu}(2016)$ & $\begin{array}{l}\text { Beijing, } \\
\text { China }\end{array}$ & $\begin{array}{l}\text { License-plate-- } \\
\text { based driving } \\
\text { restrictions } \\
\text { (modifications) }\end{array}$ & $\begin{array}{l}\text { Air pollution } \\
\text { index }\left(\mathrm{NO}_{2}\right. \\
\mathrm{SO}_{2}, \mathrm{PM} 10\end{array}$ & $\begin{array}{l}\text { City-level } \\
\text { longitudinal }\end{array}$ & $\mathrm{RD}$ & $\begin{array}{l}2009 \text { weakening of policy led to } \\
\text { increases in pollution; } 2011 \\
\text { strengthening led to reductions }\end{array}$ \\
\hline Bonilla (2016) & $\begin{array}{l}\text { Bogotá, } \\
\text { Colombia }\end{array}$ & $\begin{array}{l}\text { License plate-- } \\
\text { based driving } \\
\text { restrictions }\end{array}$ & $\begin{array}{l}\mathrm{CO}, \text { fuel } \\
\text { consumption, } \\
\text { vehicle } \\
\text { registration, } \\
\text { new vehicle } \\
\text { sales }\end{array}$ & $\begin{array}{l}\text { City-level } \\
\text { longitudinal }\end{array}$ & $\mathrm{RD}$ & $\begin{array}{l}\text { Early and late phases of program } \\
\text { had no effect on CO or vehicle } \\
\text { use; some evidence late phase } \\
\text { increased fuel consumption, } \\
\text { vehicle ownership, and CO in } \\
\text { morning peak hours }\end{array}$ \\
\hline Zhang et al. (2017) & $\begin{array}{l}\text { Bogotá, } \\
\text { Colombia }\end{array}$ & $\begin{array}{l}\text { License plate-- } \\
\text { based driving } \\
\text { restrictions }\end{array}$ & $\begin{array}{l}\mathrm{PM} 10, \mathrm{NO} \\
\mathrm{NO}_{2}, \mathrm{NO}_{x}, \mathrm{O}_{3} \\
\mathrm{SO}_{2}\end{array}$ & $\begin{array}{l}\text { City-level } \\
\text { longitudinal }\end{array}$ & $\mathrm{RD}$ & $\begin{array}{l}\text { Although effects of restrictions } \\
\text { vary across pollutants, no } \\
\text { significant improvements in } \\
\text { overall air quality }\end{array}$ \\
\hline Carrillo et al. (2016) & Quito, & License plate- & $\mathrm{CO}$ & City-level & DDD & Restrictions reduced carbon \\
\hline
\end{tabular}




\begin{tabular}{|c|c|c|c|c|c|c|}
\hline & Ecuador & $\begin{array}{l}\text { based driving } \\
\text { restrictions }\end{array}$ & & longitudinal & & $\begin{array}{l}\text { monoxide pollution by } 9-11 \% \\
\text { during peak traffic hours }\end{array}$ \\
\hline De Grange \& Troncoso (2011) & $\begin{array}{l}\text { Santiago, } \\
\text { Chile }\end{array}$ & $\begin{array}{l}\text { License plate-- } \\
\text { based driving } \\
\text { restrictions }\end{array}$ & $\begin{array}{l}\text { Automobile, } \\
\text { metro, and bus } \\
\text { trips }\end{array}$ & $\begin{array}{l}\text { City-level } \\
\text { longitudinal }\end{array}$ & $\mathrm{RD}$ & $\begin{array}{l}\text { Permanent restrictions have not } \\
\text { affected use of private vehicles } \\
\text { but additional restrictions } \\
\text { reduced private vehicle use by } \\
6 \% \text { and increased metro use by } \\
3 \%\end{array}$ \\
\hline \multicolumn{7}{|l|}{ Miscellaneous } \\
\hline Oliva (2015) & $\begin{array}{l}\text { Mexico City, } \\
\text { Mexico }\end{array}$ & $\begin{array}{l}\text { Emissions } \\
\text { standards }\end{array}$ & $\begin{array}{l}\text { Cheating } \\
\text { incidence, } \\
\text { vehicular } \\
\text { emissions } \\
\text { (among others) }\end{array}$ & $\begin{array}{l}\text { Vehicle- } \\
\text { level panel }\end{array}$ & See text & $\begin{array}{l}10 \% \text { of car owners cheated on } \\
\text { emissions tests; eliminating } \\
\text { cheating would significantly } \\
\text { reduce vehicular emissions }\end{array}$ \\
\hline Kathuria (2002) & Delhi, India & Various & $\mathrm{SPM}, \mathrm{NO}_{x}$ & $\begin{array}{l}\text { City-level } \\
\text { longitudinal }\end{array}$ & Event study & Unable to discern effect \\
\hline
\end{tabular}

*Articles are listed in the order they are discussed in the text.

$2 \mathrm{SLS}=$ two-stage least squares; $3 \mathrm{SLS}=$ three-stage least squares; $\mathrm{AOD}=$ aerosol optical depth $; \mathrm{CAC}=$ command-and-control $; \mathrm{CO}=$ carbon monoxide; $\mathrm{CO}_{2}=$ carbon dioxide; $\mathrm{COD}=$ chemical oxygen demand water pollution; $\mathrm{DDD}=$ triple difference-in-differences; $\mathrm{DID}=$ difference-in-differences; $\mathrm{DO}=$ dissolved oxygen; EMS = environmental management system; Fcoli = fecal coliforms; $\mathrm{FE}=$ fixed effect; IV = instrumental variable; $\mathrm{NO}_{2}=$ nitrogen dioxide; $\mathrm{NO}_{x}=$ nitrogen oxides; $\mathrm{O}_{3}=$ ozone; OLS = ordinary leas squares; $\mathrm{PM}=$ particulate matter; PM10 = particulate matter smaller than 10 microns; PM2.5 = particulate matter smaller than 2.5 microns; $\mathrm{RCT}=$ randomized controlled trial; $\mathrm{RD}=$ regression discontinuity; $\mathrm{SO}_{2}=$ sulfur dioxide; $\mathrm{SPM}=$ suspended particulate matter; TSS $=$ total suspended solids 
Table 2. Studies on effects of command-and-control environmental regulation in developing countries

\begin{tabular}{llll} 
Type & No. & $\begin{array}{l}\text { Some } \\
\text { benefit? }\end{array}$ & Countries \\
\hline $\begin{array}{l}\text { Stationary } \\
\quad \text { Air and water }\end{array}$ & & & \\
$\quad \begin{array}{l}\text { Panel } \\
\quad \text { Cross-sectional }\end{array}$ & 5 & 5 & India (2), China (2) \\
$\begin{array}{l}\text { Air only } \\
\quad \text { Panel }\end{array}$ & 7 & 6 & Chile (3), China (3), Mexico (1) \\
$\quad$ Cross-sectional & 0 & 0 & \\
$\begin{array}{l}\text { Water only } \\
\quad \text { Panel }\end{array}$ & 2 & 2 & China (2) \\
$\quad \begin{array}{l}\text { Cross-sectional } \\
\text { Total }\end{array}$ & 2 & 0 & China (1), Mexico (1) \\
Mobile sources & 20 & 17 & \\
$\begin{array}{l}\text { Driving restrictions } \\
\text { Miscellaneous }\end{array}$ & 10 & 6 & Mexico (3), China (3), Colombia (2), Ecuador (1), Chile (1) \\
Total & 2 & 1 & India (1), Mexico (1) \\
GRAND TOTAL & 12 & 7 & China (12), Mexico (8), Chile (4), India (3), \\
& 32 & 24 & Brazil (2), Colombia (2), Ecuador (1)
\end{tabular}


Table 3. Evidence on effects of market-based instruments in developing countries*

\begin{tabular}{|c|c|c|c|c|c|}
\hline $\begin{array}{l}\text { Regulation/ } \\
\text { Study }\end{array}$ & Category & Outcomes & Data & Method & Results \\
\hline Emissions fees & & & & & \\
\hline \multicolumn{6}{|c|}{ China's pollution levy system } \\
\hline Wang (2002) & Water & $\begin{array}{l}\text { Abatement } \\
\text { investments and } \\
\text { expenditures }\end{array}$ & $\begin{array}{l}\text { Plant-level } \\
\text { cross-section }\end{array}$ & $\begin{array}{l}\text { Instrument } \\
\text { variable }\end{array}$ & $\begin{array}{l}\text { Higher effective levy rate } \\
\text { increases abatement investments } \\
\text { and expenditures }\end{array}$ \\
\hline Wang \& Wheeler (2005) & Air and water & $\begin{array}{l}\mathrm{SO}_{2} \text { air pollution and } \\
\mathrm{COD} \text { water pollution }\end{array}$ & $\begin{array}{l}\text { Plant-level } \\
\text { cross-section }\end{array}$ & $\begin{array}{l}\text { Simultaneous } \\
\text { equations }\end{array}$ & $\begin{array}{l}\text { Higher effective levy rate } \\
\text { decreases pollutant emissions }\end{array}$ \\
\hline Jiang \& McKibbin (2002) & $\begin{array}{l}\text { Air, water, } \\
\text { and solid } \\
\text { waste }\end{array}$ & $\begin{array}{l}\text { Pollution intensities of } \\
\text { waste gas, waste } \\
\text { water, and solid waste }\end{array}$ & $\begin{array}{l}\text { Province-level } \\
\text { panel }\end{array}$ & $\begin{array}{l}\text { Simultaneous } \\
\text { equations }\end{array}$ & $\begin{array}{l}\text { Higher effective levy rate } \\
\text { decreases pollution intensities }\end{array}$ \\
\hline Jin \& Lin (2014) & Air and water & $\begin{array}{l}\mathrm{SO}_{2} \text { air pollution and } \\
\mathrm{COD} \text { water pollution }\end{array}$ & $\begin{array}{l}\text { Province-level } \\
\text { panel }\end{array}$ & Fixed effect & $\begin{array}{l}\text { Higher effective levy rate } \\
\text { decreases air pollution but not } \\
\text { water pollution }\end{array}$ \\
\hline Dasgupta et al. (2001) & Air and water & $\begin{array}{l}\text { TSS air pollution, and } \\
\text { COD and TSS water } \\
\text { pollution }\end{array}$ & Plant-level panel & $\begin{array}{l}\text { Simultaneous } \\
\text { equations }\end{array}$ & $\begin{array}{l}\text { Regulatory inspections reduce air } \\
\text { and water pollution }\end{array}$ \\
\hline Lin (2013) & Water & COD water pollution & Plant-level panel & $\begin{array}{l}\text { Instrument } \\
\text { variable }\end{array}$ & $\begin{array}{l}\text { Regulatory inspections increase } \\
\text { plants' reported total and above- } \\
\text { standard water pollution }\end{array}$ \\
\hline \multicolumn{6}{|l|}{ Tradable permits } \\
\hline Montero et al. (2002) & Air & $\begin{array}{l}\text { Adoption of natural } \\
\text { gas }\end{array}$ & $\begin{array}{l}\text { Plant-level } \\
\text { cross-section }\end{array}$ & Logit & $\begin{array}{l}\text { Permit trading did not encourage } \\
\text { switch to natural gas }\end{array}$ \\
\hline Coria (2009) & Air & $\begin{array}{l}\text { Adoption of natural } \\
\text { gas }\end{array}$ & $\begin{array}{l}\text { Plant-level } \\
\text { panel }\end{array}$ & Duration model & $\begin{array}{l}\text { Energy prices, not regulation, } \\
\text { drove switch to natural gas }\end{array}$ \\
\hline
\end{tabular}

$\mathrm{COD}=$ chemical oxygen demand water pollution; $\mathrm{SO}_{2}=$ sulfur dioxide; $\mathrm{SPM}=$ suspended particulate matter; TSS = total suspended solids. 
Table 4. Studies on effects of market-based instruments in developing countries

\begin{tabular}{lll} 
Type & No. & $\begin{array}{l}\text { Some } \\
\text { benefit? }\end{array}$ \\
\cline { 3 - 3 } Chinese pollution levies & & \\
$\quad$ Air, water and solid waste & & \\
$\quad$ Panel & 1 & 1 \\
Air and water & & \\
$\quad$ Panel & 2 & 2 \\
$\quad$ Cross-sectional & 1 & 1 \\
Water only & & \\
$\quad$ Panel & 1 & 0 \\
$\quad$ Cross-sectional & 1 & 1 \\
Total & 6 & 5 \\
Chilean tradable permit & & \\
Switch to natural gas & & \\
$\quad$ Panel & 1 & 0 \\
$\quad$ Cross-sectional & 1 & 0 \\
Total & 2 & 0 \\
GRAND TOTAL & 8 & 5
\end{tabular}

